\title{
Assessment of toxicity on the basis of total phenolic content in oleander leaves (Nerium oleander L.) against Myzus persicae (Sulzer, 1776) (Hemiptera: Aphididae)
}

\author{
Billal NIA*1 ${ }^{1}$, Naama FRAH ${ }^{2}$, Adel LEKBIR $^{3}$ and Khadidja BENHMED ${ }^{4}$
}

Received May 12, 2017; accepted May 15, 2018.

Delo je prispelo 12. maja 2017, sprejeto 15. maja 2018.

\begin{abstract}
Nerium oleander is an evergreen flowering shrub or small tree distributed widely in the Mediterranean region. It is also a source of polyphenols and cardenolides ?? with insecticidal effect which could be a safe alternative of chemical control of insect pests. In the present work, five concentrations $(0 \%$, $1 \%, 2.5 \%, 5 \%$, and $10 \%$ ) of ethanolic extract from Nerium oleander leaves were evaluated for its insecticidal effect against 3 to 4 days old Myzus persicae individuals under laboratory conditions. Obtained results showed a significant insecticidal effect with $70 \%$ of mortality at the highest concentration $(10 \%)$. Total phenolic content of leaf ethanolic extract of this plant was $1721.36 \mathrm{mg}$ gallic acid equivalent $100 \mathrm{~g}^{-1}$ dry matter. The results obtained suggest that we could make bioinsecticides based on leaves ethanolic extracts from $N$. oleander which rich in polyphenols for use eventually in integrated pest management.
\end{abstract}

Key words: Nerium oleander; Myzus persicae; insecticidal effect; total phenolic content
IZVLEČEK

OVREDNOTENJE STRUPENOSTI ETANOLNIH IZVLEČKOV FENOLOV IZ LISTOV OLEANDRA (Nerium oleander L.) ZA SIVO BRESKOVO UŠ (Myzus persicae (Sulzer, 1776), Hemiptera: Aphididae)

Oleander (Nerium oleander) je vednozelen grm, ki je razširjen $\mathrm{v}$ celotnem mediteranskem območju. Je tudi vir polifenolov in kardenolidov z insekticidnimi učinki, ki bi lahko bili varna alternativa kemijski kontroli škodljivih žuželk. V raziskavi so bili ovrednoteni insekticidni učinki etanolnih izvlečkov oleandrovih listov v petih koncentracijah $(0 \%, 1 \%, 2,5 \%$, $5 \%$, in $10 \%$ ) na smrtnost 3 do 4 dni starih sivih breskovih uši v laboratorijskih razmerah. Dobljeni izsledki so pokazali značilne insekticidne učinke s $70 \%$ smrtnostjo pri največji koncentraciji izvlečka (10\%). Celokupna vsebnost fenolov etanolnega izvlečka oleandrovih listov je bila 1721,36 mg, izražena kot ekvivalent galne kisline na $100 \mathrm{~g}^{-1}$ suhe snovi. Dobljeni rezultati nakazujejo, da bi etanolne izvlečke na polifenolih bogatih oleandrovih listov lahko uporabili $\mathrm{v}$ integriranem uravnavanju škodljivcev.

Ključne besede: Nerium oleander; Myzus persicae; insekticidni učinek; celokupna vsebnost fenolov

\section{INTRODUCTION}

Chemical pesticides used in plant protection have hazardous effects on human health and environment. Phytochemicals and plant extracts have long been a subject of research in an effort to develop alternatives to conventional insecticides but with reduced health and environmental impact (Dancewicz et al., 2011). Most plant species which are used for plant protection contain ingredients which inhibit the development of insects,

\footnotetext{
1 Department of Agronomy, Faculty of Natural and Life Sciences, Mohamed Khider University of Biskra, Algeria / Scientific and technical research in arid regions (CRSTRA), Biskra, Algeria; ${ }^{*}$ Corresponding author: e-mail: bnagro@ yahoo.fr

2 Department of Agronomy, Institute of Veterinary and Agricultural Sciences, Hadj Lakhdar University of Batna, Algeria

3 Food Science Laboratory, Department of Food Technology, Institute of Veterinary and Agricultural Sciences, Hadj Lakhdar University of Batna, Algeria

4 Scientific and technical research in arid regions (CRSTRA), Biskra, Algeria
} 
hinder their feeding (antifeedants) or act as repellents and confusants (Rojht et al., 2009, Laznik et al., 2010, Rojht et al., 2012.). Polyphenols are a reputed and large phytochemical family with many interesting properties such plant resistance to insect pests (Bennett, 1996, Ding et al., 2000), antioxidant activity (Emmons and Peterson, 2001), and organoleptic properties (Es-Safi et al., 2003).

The green peach aphid, Myzus persicae (Sulzer, 1776) is found throughout the world. In addition to attacking plants in the field, the aphid readily infests vegetables and ornamental plants grown in greenhouses (Capinera, 2011). It is also an insect model for many studies ( $\mathrm{Ji}$ et al., 2016). Its management is generally based upon the use of synthetic insecticides (Ciarla et al., 2005). Consequently, this study aims to assess the toxicity of Nerium oleander L. ethanolic leaf extract against $M$. persicae and determine the content of phenolic compounds of this extract due to its richness in these molecules which implicated in pest control in order to valorize the role of this plant in this field.

\section{MATERIALS AND METHODS}

$N$. oleander leaves were collected in April 2014 at the flowering stage from Batna in the East of Algeria. It is located at $35^{\circ} 61^{\prime} \mathrm{N}, 6^{\circ} 24^{\prime} \mathrm{E}$ with an elevation of 641 meters above sea level. Leaves were dried at $50{ }^{\circ} \mathrm{C}$ and ground to a fine powder in a mortar grinder (Retsch RM 200). The air-dried and finely ground leaves ( $80 \mathrm{~g})$ were extracted by successive extraction three times. Indeed, the powder was stirred with $400 \mathrm{ml}$ of ethanol at room temperature for $30 \mathrm{~min}$. The mixture was filtered three times to obtain three filtrates. These three filtrates were mixed and brought together in a sand bath (N'guessan et al., 2009). These series of operations resulted in a concentrated solution. The extract was kept at $+4 \mathrm{C}^{\circ}$ until toxicity test on the aphid and determination of total phenolic content.

\subsection{Aphid collecting and rearing}

Last stage larvae of green peach aphid have been collected collected from Biskra in the South East of Algeria at $34^{\circ} 52^{\prime} \mathrm{N}, 5^{\circ} 45^{\prime} \mathrm{E}$ in April 2014 where they were living on Malva sp. Mass rearing of the green peach aphid was started on broad beans (Vicia faba L.) in a greenhouse. Each plant was inoculated with an apterous adult when emerging in the morning. Aphids were collected after 10 days by brushing them carefully from the leaves.

\subsection{Preparation of dilutions}

Five dilutions have been made: $0,1,2.5,5$ and $10 \%$. These were prepared by adding the methanol according to the protocol of Singh et al. (2012).

\subsection{Bioassay test}

To assess the insecticidal effect of $N$. oleander leaf extract, $15 \mathrm{M}$. persicae larvae (3 to 4 days old) per treatment were placed in a Petri dish $(90 \mathrm{~mm})$ containing three leaves of Vicia faba soaked in these different concentrations with three replications. The experiment was carried out under laboratory conditions $\left(25 \pm 1{ }^{\circ} \mathrm{C}, 50 \pm 5 \%\right)$. The mortality was determined after $24 \mathrm{~h}$ from the beginning of exposure. When no leg or antennal movements were observed, insects were considered dead (Salari et al., 2010).

\subsection{Total phenolic content}

The total phenolic content of the ethanolic extract of $N$. oleander L. was measured by the method described by Juntachote (2007). $0.5 \mathrm{ml}$ of the extract was added to $5 \mathrm{ml}$ of distilled water and vortexed for $1 \mathrm{~min}$ using a vortex mixer (Janke \& Kunkel IKA, Model: VF2, Germany). $1 \mathrm{ml}$ of Folin and Ciocalteu's Phenolic reagent was added and mixed well. After $5 \mathrm{~min}, 1 \mathrm{ml}$ of saturated sodium carbonate solution was added and the mixture was vortexed again. The sample was allowed to develop a blue colour for $1 \mathrm{~h}$. The absorbance was measured at $640 \mathrm{~nm}$ using a spectrophotometer (UV120-01; Shimadzu Co., Kyoto, Japan). A standard curve was prepared at the same time with gallic acid (SigmaAdrich $\mathrm{GmbH}$, Sternheim, Germany) at concentrations ranging from 0 to $0.2 \mathrm{mg} \mathrm{ml}^{-1}$. The quantity of total phenolic content in the sample was calculated as gallic acid equivalent by using the standard curve.

\subsection{Statistical analysis}

Logistic regression analysis was employed to predict the probability that the augmentation of ethanolic extract concentrations would increase mortality of $M$. persicae individuals. The predictor variable was ethanolic extract concentrations $(1 \%, 2.5 \%, 5 \%$, and $10 \%)$. The Chisquare value will determine whether there is a difference between the current model and the interceptonly model. We used the statistical program Statistica 8 (StatSoft, Inc., Tulsa, OK) for all analyses. 


\section{RESULTS AND DISCUSSION}

Nerium oleander (common oleander) is potentially lethal plant after ingestion for human beings, all parts of this plant are toxic (Bandara et al., 2010). It has antimicrobial properties (Huq et al., 1999; El Sawi et al., 2010), antioxidant activity (Mohadjerani, 2012) and also insecticide effect (Bagari et al., 2013).

Statistical analysis indicated the presence of dependence between the mortality and the different concentrations $(p<0.01)$. The Chi-square value for the difference between the current model and the intercept-only model is highly significant. Thus, we can conclude that mortality is related to ethanolic extract concentrations. In fact, Table 1 shows the logistic regression coefficient, Wald test and odds ratio. Using a 0.05 criterion of statistical significance showed that all concentrations had significant effect (Table 1).

Table 1: Logistic regression predicting mortality from concentrations and lethal concentration $\left(\mathrm{LC}_{50}\right.$ and $\left.\mathrm{LC}_{90} \%\right)$

\begin{tabular}{c|c|c|c|c|c|c}
\hline$\chi^{2}$ & B & Wald $\chi^{2}$ & $P$ & Odds Ratio & $\mathrm{LC}_{50}(\%)$ & $\mathrm{LC}_{90}(\%)$ \\
\hline 74.81 & -2.6 & 62 & 0.000 & 1.43 & 7.2 & 9.85 \\
\hline
\end{tabular}

A concentration of $10 \%$ caused $73 \%$ of mortality on green peach aphid (Figure 1) with a $\mathrm{LC}_{50}$ of $7.2 \%$ while $\mathrm{LC}_{90}$ was $9.85 \%$.

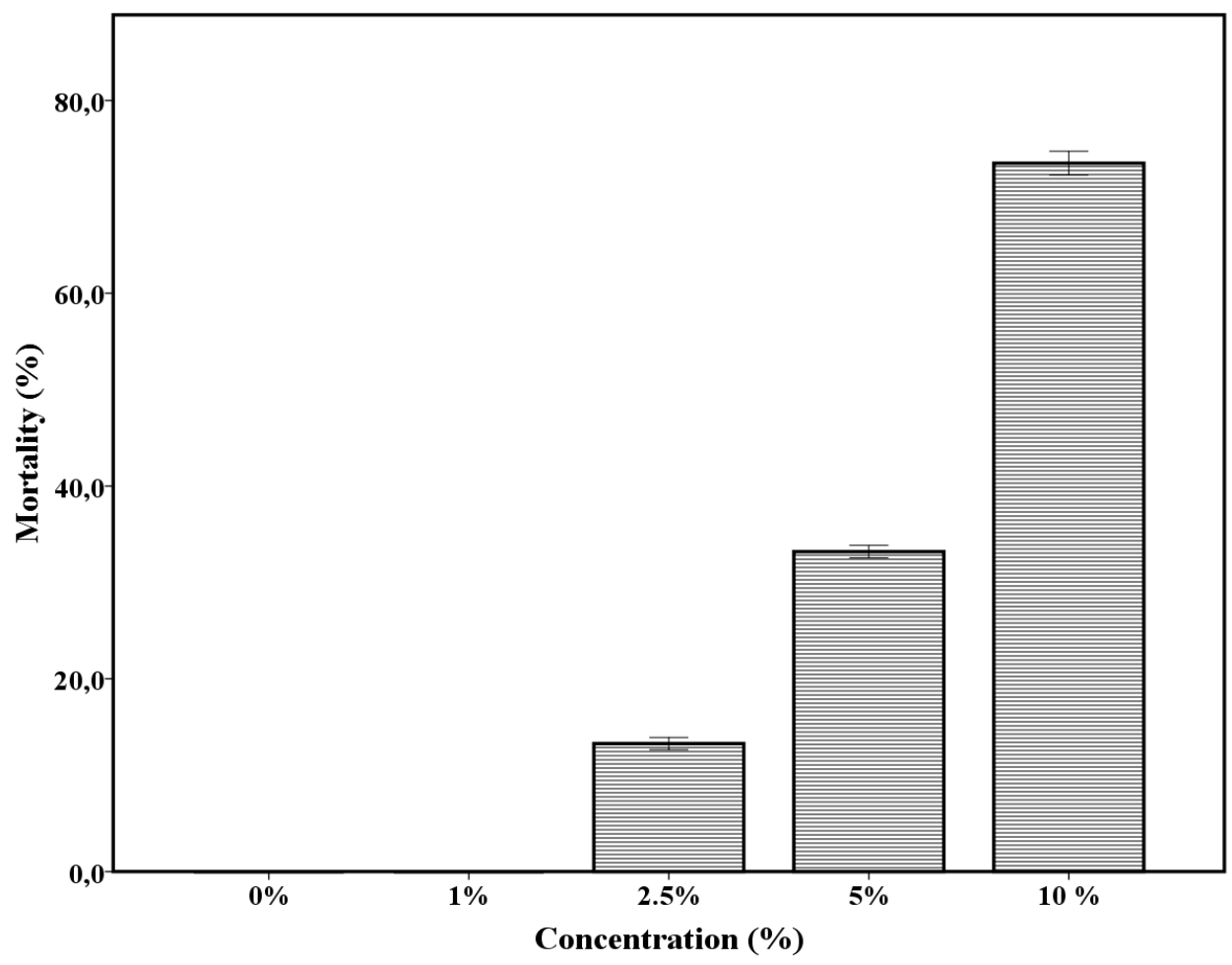

Figure 1: Average mortality ( $\% \pm$ standard error) of Myzus persicae larvae with leaf extracts from Nerium oleander with several concentrations after 24 hours

The toxicity of $2 \%$ crude phenol extract of the leaves of $N$. oleander on larvae and adults of Bemisia tabaci (Gennadius, 1889) (Hemiptera: Aleyrodidae) reached $82.63 \%$ and $60.45 \%$ respectively (Rathi and Zubaidi,
2011). The extract hydro-alcoholic of its leaves administred to larvae of the tribe Rhizotrogini (Coleoptera: Scarabaeidae) had an effect on the protein 
content of the haemolymph and acetylcholine esterase activity (Madaci et al., 2008).

In the literature, many authors had mentioned the richness of $N$. oleander (Madaci et al., 2008; Rathi and Zubaidi, 2011; Siddiqui et al., 2012).
Based on the absorbance values of phenolic extract reacting with the Folin-Ciocalteu, and compared to the standard gallic acid solution, the result of the quantitative analysis of total phenolic compounds was $1721.36 \mathrm{mg}$ gallic acid equivalent $100 \mathrm{~g}^{-1}$ of DR (dry matter) (Figure 2).

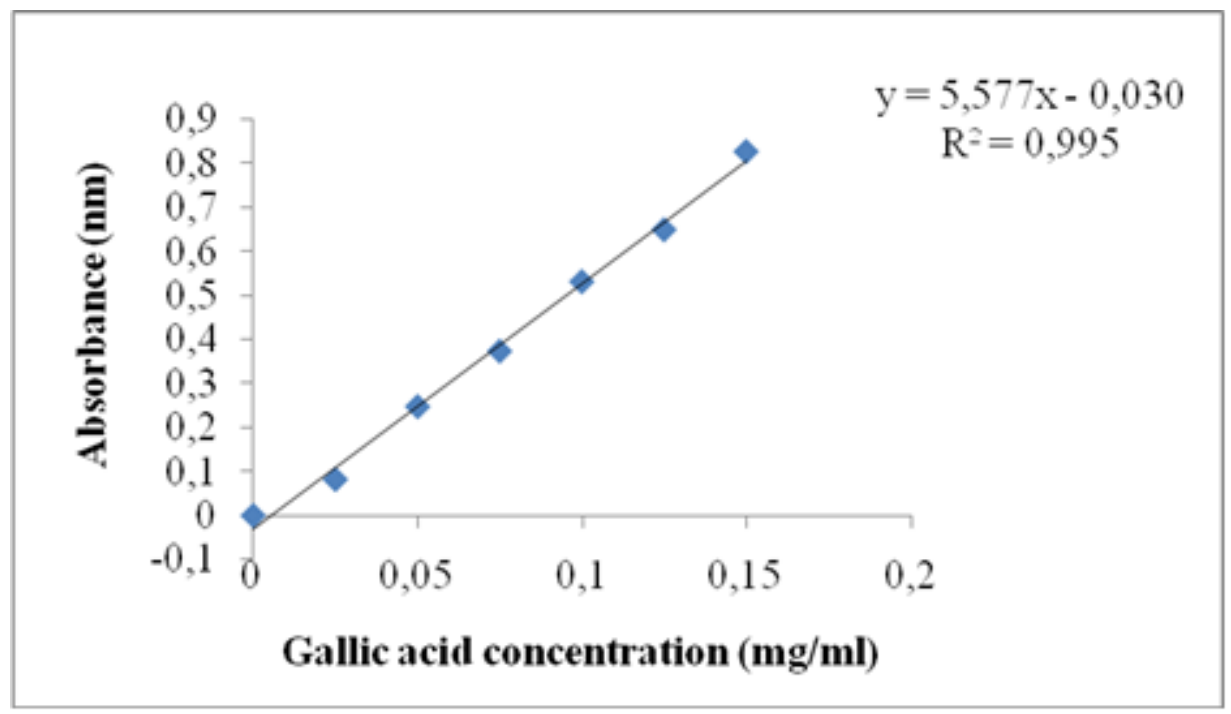

Figure 2: Total phenolic content in leaves of Nerium oleander

Our results and those obtained by Zibbu (2012) and Mohadjerani (2012) who found $48.94 \mathrm{mg}$ equivalent catechol $100 \mathrm{mg}^{-1}$ dry matter and $4.54 \mu \mathrm{g}$ gallic acid $100 \mu^{-1}$ dry matter respectively. Also, Srivastava et al. (2013) found $30.10 \mathrm{mg}$ EAG $100 \mathrm{~g}^{-1}$ but in fresh mass indicated the high amounts of these molecules contained in leaves of common oleander.

High toxicity against green peach aphid individuals was due probably to the high amounts of phenolic compounds present in the extract. Indeed, many authors have highlighted the importance of polyphenols for aphid control which support our findings. Indeed, Laznik (2010) tested cinnamic acid against Aphis pomi (De Geer, 1773) and found that this molecule has showed aphicidal properties. Also, two flavanoles and one flavanone were found to be active as aphicid against the woolly apple aphid, Eriosoma lanigerum (Hausmann, 1802) by Ateyyat et al. (2012). In fact, larval mortality was higher than that obtained against apterous adults. The increase in the concentration of polyphenols has resulted in a remarkable augmentation in the larval mortality rate. However, works on aphicidal activity of $N$. oleander are very scarce. Goławska $(2012$, 2008) reported the effectiveness of polyphenols against Acyrthosiphon pisum (Harris, 1776). El-Akhal et al. (2015) tested the ethanolic extract of $N$. oleander on culicid mosquitoes and noticed toxic effects on their larvae. Indeed, the lowest concentration necessary to achieve $100 \%$ mortality of Culex pipiens (Linné, 1758) larvae was evaluated at $160 \mathrm{mg} \mathrm{ml}^{-1}$.

\section{CONCLUSIONS}

Leaf ethanolic extract of $N$. oleander was effective against green peach aphid and this efficacy is probably due to the high content of this extract on polyphenols. Thus, the results obviously show that will be possible to develop new biopesticides based on high content of these molecules in integrated pest management programs to reduce the use of conventional insecticides. Nevertheless, further research is needed on the phytotoxicity of these molecules and toxicity against non-target species. 


\section{REFERENCES}

Ateyyat, M., Abu-Romman, S., Abu-Darwish, M., \& Ghabeish, I. (2012). Impact of flavonoids against woolly apple aphid, Eriosoma lanigerum (Hausmann) and its sole parasitoid, Aphelinus mali (Hald.). World Applied Sciences Journal, 16(8), 1060-1064.

Bagari, M., Bouhaimi, A., Ghaout, S., \& Chihrane, J. (2013). The toxic effects of Nerium oleander on larvae of the desert locust Schistocerca gregaria (Forskål, 1775) (Ortoptera: Acrididae). Zoologica Baetica, 24, 193-203.

Bandara, V., Weinstein, S. A., White, J., \& Eddleston, M. (2010). A review of the natural history, toxinology, diagnosis and clinical management of Nerium oleander (common oleander) and Thevetia peruviana (yellow oleander) poisoning. Toxicon, 56(3), 273-281. doi:10.1016/j.toxicon.2010.03.026

Bennett, M., Gallagher, M., Fagg, J., Bestwick, C., Paul, T., Beale, M., \& Mansfield, J. (1996). The hypersensitive reaction, membrane damage and accumulation of autofluorescent phenolics in lettuce cells challenged by Bremia lactucae. The Plant Journal, 9(6), 851-865. doi:10.1046/j.1365313X.1996.9060851.x

Capinera, J. (2011). Green peach aphid, Myzus persicae (Sulzer)(Hemiptera: Aphididae). University of Florida, 1-10.

Ciarla, M. V, Mareggiani, G., Heit, G., \& Puhl, L. (2005). Myzus persicae (Homoptera: Aphididae) and Capsicum annuum (Solanaceae) volatiles: their effect on predators attraction. Boletín de Sanidad Vegetal Plagas, 31, 503-507.

Dancewicz, K., Gabryś, B., \& Przybylska, M. (2011). Effect of garlic ( Allium sativum L .) and tansy ( Tanaceum vulgare L .) extracts and potassic horticultural soap on the probing and feeding behaviour of Myzus persicae ( Sulzer , 1776 ). Aphids and Other Hemipterous Insects, 17, 129136.

Ding, H., Lamb, R. J., \& Ames, N. (2000). Inducible production of phenolic acids in wheat and antibiotic resistance to Sitodiplosis mosellana. Journal of Chemical Ecology, 26(4), 969-985. doi:10.1023/A:1005412309735

El-Akhal, F., Guemmouh, R., Zoubi, Y. E., El, A., \& Lalami, O. (2015). Larvicidal activity of Nerium oleander against larvae west nile vector mosquito Culex pipiens ( Diptera: Culicidae ). Journal of Parasitology Research, 2015, 5. doi:10.1155/2015/943060
El Sawi, N. M., Geweely, N. S., Qusti, S., Mohamed, M., \& Kamel, A. (2010). Cytotoxicity and antimicrobial activity of Nerium oleander extracts. Journal of Applied Animal Research, 37(1), 25-31. doi:10.1080/09712119.2010.9707089

Emmons, C. L., \& Peterson, D. M. (2001). Antioxidant activity and phenolic content of oat as affected by cultivar and location. (Crop Breeding, Genetics \&amp; Cytology). Crop Science, 41(6), 1676-1682. doi:10.2135/cropsci2001.1676

Es-Safi, N. E., Cheynier, V., \& Moutounet, M. (2003). Implication of phenolic reactions in food organoleptic properties. Journal of Food Composition and Analysis, 16(5), 535-553. doi:10.1016/S0889-1575(03)00019-X

Goławska, S., Kapusta, I., Łukasik, I., \& Wójcicka, A. (2008). Effect of phenolics on the pea aphid, Acyrthosiphon pisum ( Harris ) population on Pisum sativum L . ( Fabaceae ). Pestycydy/Pesticides, 3-4, 71-77.

Goławska, S., \& Łukasik, I. (2012). Antifeedant activity of luteolin and genistein against the pea aphid, Acyrthosiphon pisum. Journal of Pest Science, 85, 443-450. doi:10.1007/s10340-012-0452-z

Huq, M. M., Jabbar, A., Rashid, M. A., \& Hasan, C. M. (1999). A novel antibacterial and cardiac steroid from the roots of Nerium oleander. Fitoterapia, 70(1), 5-9. doi:10.1016/S0367-326X(98)00013-6

Ji, R., Wang, Y., Cheng, Y., Zhang, M., Zhang, H.-B., Zhu, L., ... Zhu-Salzman, K. (2016). Transcriptome Analysis of Green Peach Aphid (Myzus persicae): Insight into Developmental Regulation and InterSpecies Divergence. Frontiers in Plant Science, 7(October), 1-12. doi:10.3389/fpls.2016.01562

Juntachote, T., Berghofer, E., Siebenhandl, S., \& Bauer, F. (2007). Antioxidative effect of added dried Holy basil and its ethanolic extracts on susceptibility of cooked ground pork to lipid oxidation. Food Chemistry, 100(1), 129-135. doi:10.1016/j.foodchem.2005.09.033

Laznik, Ž., Cunja, V., Kač, M., \& Trdan, S. (2011). Efficacy of three natural substances against apple aphid (Aphis pomi De Geer, Aphididae, Homoptera) under laboratory conditions. Acta Agriculturae Slovenica, 97(1), 19-23. doi:10.2478/v10014-011-0003-y

Madaci, B., Merghem, R., Doumandji, B., \& Soltani, N. (2008). Effet du Nerium oleander, laurier-rose, (Apocynacees) sur le taux des proteines, l'activite de l'ache et les mouvements des vers blancs 
Billal NIA et al.

Rhizotrogini, (Colepoptera: Scarabaeidae). Sciences and Technologie, 27, 73-78.

Mohadjerani, M. (2012). Antioxidant Activity and Total Phenolic Content of Nerium oleander L. Grown in North of Iran. Iranian Journal of Pharmaceutical Research : IJPR, 11(4), 1121-6.

N'Guessan, K., Kadja, B., Zirihi, G., Traoré, D., \& AkéAssi, L. (2009). Screening phytochimique de quelques plantes médicinales ivoiriennes utilisées en pays Krobou (Agboville, Côte-d'Ivoire). Sciences \& Nature, 6(1), 1-15. doi:10.4314/scinat.v6i1.48575

Rathi, M. H., \& Zubaidi, F. S. A. (2011). Effect of crude phenolic extracts of Nerium oleander L . leaves on the biological performance of Bemisia tabaci ( Genn .) ( Homoptera : Aleyrodida ). Diyala Journal for Pure Sciences, (July), 214-226.

Rojht, H., Meško, A., Vidrih, M., \& Trdan, S. (2009). Insecticidal activity of four different substances against larvae and adults of sycamore lace bug (Corythucha ciliata [Say], Heteroptera, Tingidae). Acta Agriculturae. Slovenica, 93(1), 31 - 36. doi:10.2478/v10014-009-0004-2

Rojht, H., Košir, I.J., \& Trdan, S. (2012). Chemical analysis of three herbal extracts and observation of their activity against adults of Acanthoscelides obtectus and Leptinotarsa decemlineata using a video tracking system. Journal of Plant Diseases and Protection, 119(2), 59-67. doi:10.1007/BF03356421

Salari, E., Ahmadi, K., \& Zamani, R. (2010). Study on the effects of acetonic extract of Otostegia Persica (Labiatae) on three aphid species and one stored product pest. Advances in Environmental Biology, 4(3), 346-349.

Siddiqui, B. S., Khatoon, N., Begum, S., Dar Farooq, A., Qamar, K., Aslam Bhatti, H., \& Kashif, S. (2012). Phytochemistry Flavonoid and cardenolide glycosides and a pentacyclic triterpene from the leaves of Nerium oleander and evaluation of cytotoxicity. Phytochemistry, 77, 238-244. doi:10.1016/j.phytochem.2012.01.001

Singh, C., Pandey, D. N., \& Shukla, S. (2012). Pesticidal effect of Euphorbia, Nerium and Calotropis latex on some larvae of crop damagining pests. Internatinal Journal of Pharmacy and Pharmaceutical Science, 2, 256-260.

Srivastava, M. P., Tiwari, R., \& Sharma, N. (2013). Assessment of phenol and flavonoid content in the plant materials. Journal on New Biological Reports, 2(2), 163-166.Zibbu, G., \& Batra, A. (2012). In vitro and in vivo determination of phenolic contents and antioxidant activity of desert plants of Apocynaceae family. Asian Journal of Pharmaceutical and Clinical Research, 5(SUPPL.1), 75-83. 